\title{
A Fine-scale Assessment of Using Barriers to Conserve Native Stream Salmonids: A Case Study in Akokala Creek, Glacier National Park, USA
}

\author{
Clint C. Muhlfeld ${ }^{1, *}$, Vincent D' Angelo ${ }^{1}$, Steven T. Kalinowski ${ }^{2}$, Erin L. Landguth ${ }^{3}$, Christopher \\ C. Downs ${ }^{4}$, Joel Tohtz ${ }^{5}$, and Jeffrey L. Kershner ${ }^{6}$ \\ ${ }^{1}$ U.S. Geological Survey, Northern Rocky Mountain Science Center, Glacier National Park, West Glacier, MT \\ 59936, USA \\ ${ }^{2}$ Montana State University, Department of Ecology, Bozeman, MT 59717, USA \\ ${ }^{3}$ University of Montana, Division of Biological Sciences, Missoula, MT 59812, USA \\ ${ }^{4}$ National Park Service, Glacier National Park, West Glacier, MT 59936, USA \\ ${ }^{5}$ Montana Fish, Wildlife \& Parks, Kalispell, MT 59901, USA \\ ${ }^{6}$ U.S. Geological Survey, Northern Rocky Mountain Science Center, Bozeman, MT 59715, USA
}

\begin{abstract}
Biologists are often faced with the difficult decision in managing native salmonids of where and when to install barriers as a conservation action to prevent upstream invasion of nonnative fishes. However, fine-scale approaches to assess long-term persistence of populations within streams and watersheds chosen for isolation management are often lacking. We employed a spatially-explicit approach to evaluate stream habitat conditions, relative abundance, and genetic diversity of native westslope cutthroat trout (Oncorhynchus clarkii lewisi) within the Akokala Creek watershed in Glacier National Park- a population threatened by introgressive hybridization with nonnative rainbow trout (O. mykiss) from nearby sources. The systematic survey of 24 stream reaches showed broad overlap in fish population and suitable habitat characteristics among reaches and no natural barriers to fish migration were found. Analysis of population structure using 16 microsatellite loci showed modest amounts of genetic diversity among reaches, and that fish from Long Bow Creek were the only moderately distinct genetic group. We then used this information to assess the potential impacts of three barrier placement scenarios on long-term population persistence and genetic diversity. The two barrier placement scenarios in headwater areas generally failed to meet general persistence criteria for minimum population size $(2,500$ individuals, $N_{e}=500$ ), maintenance of long-term genetic diversity $\left(H_{e}\right)$, and no population subdivision. Conversely, placing a barrier near the stream mouth and selectively passing non-hybridized, migratory spawners entering Akokala Creek met all persistence criteria and may offer the best option to conserve native trout populations and life history diversity. Systematic, fine-scale stream habitat, fish distribution, and genetic assessments in streams chosen for barrier installation are needed in conjunction with broader scale assessments to understand the potential impacts of using barriers for conservation of native salmonid populations threatened by nonnative fish invasions.
\end{abstract}

Keywords: Barriers, Genetic structure, Invasions, Westslope cutthroat trout, Oncorhynchus clarkii lewisi, Salmonids, Stream fish, Isolation, CDFISH, Heterozygosity.

\section{INTRODUCTION}

Aquatic invasive species are one of the greatest threats to native species and ecosystems worldwide [1]. Nonnative fish introductions are a primary factor contributing to biotic homogenization of freshwater systems [2], and have been implicated in the demise and extinction of many fish species [3, 4]. This is particularly true for native trout and salmon, which require streams and lakes with cold, high-quality habitats [5]. In western North America, the distributions and abundances of many native trout populations have declined

*Address correspondence to this author at the U. S. Geological Survey, Northern Rocky Mountain Science Center, Glacier National Park, West Glacier, MT 59936, USA; Tel: 406 888.7926; Fax: 406 888.7923;

E-mail: cmuhlfeld@usgs.gov due to habitat loss and competition and hybridization with introduced salmonids [5, 6]. In many situations these declines are expected to continue due to increasing rates of species introductions, persistent range expansion of invasive species, continued habitat degradation and fragmentation, and potential changes in water quality and quantity related to climate warming [7]. As a result, many remaining trout populations are restricted to small, fragmented headwater habitats in protected areas where their long-term sustainability is uncertain [8].

Isolation management with artificial barriers is often used as a conservation strategy for native trout in small headwater streams. This approach, however, may increase the threat of local extinction because individuals are restricted to small stream habitats, which are susceptible to natural disturbances, such as flooding, wildfire and drought, and small 


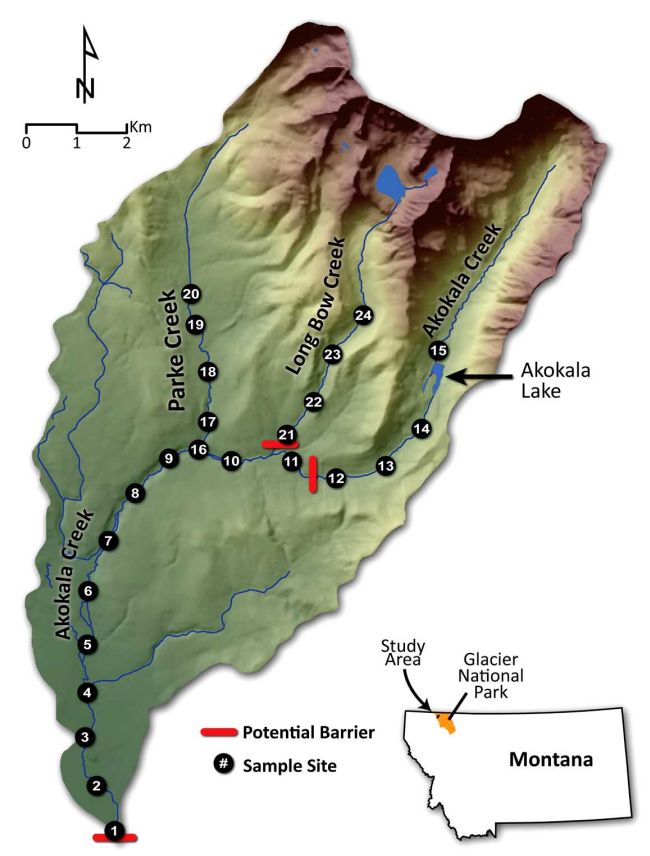

Fig. (1). Sampling sites in the Akokala Creek watershed and the potential barrier locations assessed in the study.

population sizes are inherently vulnerable to demographic and genetic stochasticity [9]. Consequently, resource managers are often faced with the decision of choosing isolation management strategies to prevent upstream movements of nonnative fishes against maintaining or restoring connectivity to conserve native populations [10-13]. This management paradigm is faced by resource managers interested in protecting critical populations and species adaptations across the landscape, but stream-specific data to inform the decision making process when streams are chosen for isolation management are limited in most situations.

Isolation management may lead to a loss of genetic and life history diversity, reduced population resilience, and can potentially lead to local population extinction of the native target species [14]. Successful development of effective isolation management strategies to conserve imperiled species depends on identifying conservation units that maximize functional adaptive genetic diversity and that preserve locally adapted populations as reflected in patterns of genetic divergence [15]. However, prioritization of populations for conservation is difficult when genetic variation is subdivided among many populations distributed across large geographical areas [16-18]. This is often the case for species inhabiting heterogeneous landscapes, such as large freshwater river systems, where populations may occur in isolation or as part of a complex metapopulation [19]. For example, westslope cutthroat trout (Oncorhynchus clarkii lewisi) and threatened bull trout (Salvelinus confluentus) exhibit high levels of genetic differentiation, even across small geographic distances, which is largely attributed to precise homing of migratory individuals to natal streams or reduced gene flow between fragmented resident populations [20-22]. Distinct populations are also maintained by natural geographic isolation caused by barriers to upstream fish migration (i.e., waterfalls or extreme water velocities), large fluvial distances between populations, or fragmentation of suitable habitat. Recent population declines, due to anthropogenic factors such as habitat destruction, fragmentation and introduction of nonnative species (and subsequent hybridization and competition), have further pronounced genetic divergence of connected local salmonid populations. Thus, a thorough consideration of these factors is necessary to analyze isolation management tradeoffs at multiple spatial and temporal scales, and is required to make informed management and conservation decisions to preserve the genetic and evolutionary legacy of populations, subspecies and species [10].

Glacier National Park (GNP) is a regional stronghold for native salmonids, including westslope cutthroat trout and bull trout, but populations are increasingly threatened by adverse interactions with nonnative salmonids. Nonnative lake trout (Salvelinus namaycush) have displaced and replaced native bull trout as the dominant predator in most of the large lakes west of the Continental Divide in GNP [23, 24], as they have in several other systems throughout the upper Columbia River drainage [25]. Non-hybridized westslope cutthroat trout in these same systems are threatened by introgressive hybridization with introduced rainbow trout $(O$. mykiss) [26], which is rapidly spreading upstream via continent-island and stepping-stone invasion [27, 28]. Therefore, there is an urgent need to protect extant native species assemblages to prevent further population losses in GNP and elsewhere.

Understanding the tradeoffs in managing native salmonids with barriers to upstream movement of invasive fishes is crucial for conserving native populations and ecosystems. Fausch et al., (2006) proposed a conceptual framework to consider tradeoffs in using barriers to conserve native stream fishes in stream networks, and provided general guidelines for prioritization and decisions for barrier placement in streams. The framework addresses threats of local extinction, conservation values and prioritization among populations. However, few studies have evaluated the potential demographic and genetic impacts of various barrier placement alternatives on native salmonid populations in streams chosen for isolation management. Here we present a case study to assess the potential impacts of isolation with various artificial barrier placement scenarios on westslope cutthroat trout populations in the Akokala Creek watershed in GNP (Fig. 1). The Akokala Creek watershed represents one of the largest populations of non-hybridized westslope cutthroat trout on the west side of the Continental Divide in GNP [27, 28], and also supports an adfluvial population of bull trout in Akokala Lake in the headwaters [29]. However, these populations of high conservation value are at risk of invasion by proximate sources of nonnative salmonids (i.e., lake trout and rainbow trout). In addition, the lower portion of the drainage supports a spawning run of migratory westslope cutthroat trout from downstream Flathead Lake, where pressures from various nonnative species have resulted in reductions in abundance of these native salmonids [30]. Managers are, therefore, considering various alternatives to protect this unique native species stronghold through construction of an upstream fish passage barrier, while also seeking to minimize potential impacts to life history diversity and long-term persistence of native salmonid populations. 
Fish populations can have complex genetic structures and life histories that make it difficult to formulate rules for placing barriers that are appropriate for all circumstances. However, to the extent possible, barriers should coincide with natural genetic divisions within watersheds and should not divide populations that are genetically homogeneous. Furthermore, populations isolated by barriers should be large enough and have suitable habitats necessary for long-term population viability. In this investigation, we employed a spatially-explicit approach to evaluate stream habitat conditions, relative abundance and genetic diversity of native westslope cutthroat trout within the Akokala Creek watershed in GNP. We used this information to evaluate the potential impacts of three potential barrier locations on longterm population persistence of isolated stream segments using four criteria: (1) availability of suitable trout habitat; (2) a minimum population size of 2,500 individuals (i.e., $\mathrm{Ne} \cong 500$ ); (3) no population subdivision; and (4) maintenance of genetic diversity over 50 generations. We conclude with a discussion of the best alternative that meets all these criteria to maintain genetic integrity, long-term persistence and life history diversity.

\section{MATERIALS AND METHODOLOGY}

\section{Study Area}

The upper Flathead River drainage begins in the Rocky Mountains of northwestern Montana, USA, and British Columbia, Canada, in the headwaters of the Columbia River Basin. This $18,400 \mathrm{~km}^{2}$ drainage includes the North Fork, Middle Fork, South Fork, and main stem Flathead rivers and Flathead Lake. Streams in northwestern GNP begin at the Continental Divide in the Livingston Range (2,500-3,000 m) and descend quickly through narrow, glaciated valleys punctuated by numerous cirque and moraine lakes. Our study was conducted in the Akokala Creek watershed $\left(106 \mathrm{~km}^{2} ; 6^{\text {th }}\right.$ order HUC unit) in northwestern GNP, USA (Fig. 1).

The Akokala Creek watershed is considered a regional stronghold for non-hybridized westslope cutthroat trout and bull trout $[28,31]$. Westslope cutthroat trout likely exhibit migratory (i.e., adfluvial and fluvial) and resident life histories in the Akokala watershed [32], and the population is genetically divergent from other populations in the basin [28]. Resident fish remain in their natal stream throughout their lives, whereas migratory westslope cutthroat trout rear in their natal stream for 1-4 years and then migrate downstream to mainstem rivers (fluvial) or Flathead Lake (adfluvial) to rear before returning to their natal stream to spawn [20,33]. Migratory westslope cutthroat trout radiotagged in the Flathead River have been documented spawning in the lower portion of the watershed [32]. However, one individual with low levels of rainbow trout admixture also recently spawned in these areas [32], suggesting that risk of hybridization spreading into Akokala Creek is high, and may not be limited by environmental factors [34]. Furthermore, hybridization has been shown to rapidly reduce fitness in native populations [26], which may reduce resiliency and adaptation in native populations.

\section{Barrier Placement Scenarios and Criteria}

The Akokala Creek watershed is a roadless watershed located in a National Park with few locations that are logistically practical for constructing a barrier. Therefore, for a starting point for our analysis, we identified three logistically feasible locations for placing a barrier (Fig. 1).

- Scenario 1, would isolate the entire Akokala Creek watershed by placing a barrier near the confluence of Akokala Creek and the North Fork of the Flathead River potentially at the North Fork Road bridge crossing. This option would provide $36.6 \mathrm{~km}$ of isolated stream habitat but eliminate access by migratory fish from the wider Flathead watershed.

- Scenario 2, placing a barrier on upper Akokala Creek above the confluence with Long Bow Creek, would isolate $8.6 \mathrm{~km}$ of stream habitat, in addition to Akokala Lake, while leaving $28 \mathrm{~km}$ accessible to migratory westslope cutthroat trout from the wider Flathead River drainage. An existing trail crossing is the best barrier location for this option because the channel is confined and the trail system could be used to transport equipment to the site for barrier construction.

- Scenario 3, involves placing a barrier on Long Bow Creek near its confluence with Akokala Creek and will provide the least amount of isolated habitat (5.3 $\mathrm{km}$ ), but leave the largest portion of the watershed open to migratory fish $(31.3 \mathrm{~km})$. This barrier option is logistically the most difficult of the three due to the remoteness of the site and the relatively unconfined channel type near the confluence of Long Bow and Akokala creeks. Moreover, this barrier location would not secure the bull trout population in Akokala Lake from lake trout invasion from nearby sources.

\section{Fish Population and Habitat Surveys}

We used a systematic, basin-wide fish population and habitat inventory to derive spatially-explicit estimates of stream habitat characteristics and fish distributions throughout the Akokala Creek watershed. This approach has been shown to minimize errors of extrapolation from a few small sections of stream to the entire system to account for the spatial variation in fish and habitat within a particular watershed [35]. The perennial stream network was classified into four stream sections based on changes in stream gradient, sinuosity, and the addition of tributaries. Stream sections included: the mainstem Akokala Creek from the mouth upstream to the confluence with Long Bow Creek (lower Akokala Creek); the mainstem Akokala Creek upstream from the confluence with Long Bow Creek (upper Akokala Creek); Long Bow Creek; and Parke Creek. The stream length of each section was estimated using a digital elevation model and a hydrography layer in ArcGIS 9.3 (ESRI, Redlands, CA). We assumed that the potential fish distribution extended upstream to reaches exceeding $10 \%$ gradient, owing to barriers to fish migration or inadequate habitat conditions [36].

Stream habitat characteristics and distributions were evaluated at 24 sites (reaches) sampled systematically at 1 
Table 1. Attributes of 24 Sites Sampled in Akokala, Parke and Long Bow Creeks, Summer 2009. Abbreviations are: LWD = Large Woody Debris; WCT = Westslope Cutthroat Trout; SS = Sand and Silt; SG = Small Gravel; LG = Large Gravel; CB = Cobble; BO $=$ Boulders

\begin{tabular}{|c|c|c|c|c|c|c|c|c|c|}
\hline $\begin{array}{c}\text { Site } \\
\text { Code }\end{array}$ & $\begin{array}{l}\text { Elevation } \\
(\mathbf{m})\end{array}$ & $\begin{array}{c}\text { Site } \\
\text { Length } \\
\text { (m) }\end{array}$ & $\begin{array}{l}\text { Mean Wetted } \\
\text { Width }(\mathbf{m})\end{array}$ & $\begin{array}{l}\text { Pool Density } \\
\left(\text { no./100m }{ }^{2}\right)\end{array}$ & $\begin{array}{c}\text { LWD Density } \\
\left(\text { no./100m }{ }^{2}\right)\end{array}$ & $\begin{array}{c}\text { Average } \\
\text { Gradient }(\%)\end{array}$ & $\begin{array}{l}\text { Dominant/Subdomi- } \\
\text { nant substrate }\end{array}$ & $\begin{array}{l}\text { WCT Abundance } \\
\text { (fish } \geq 75 \mathrm{~mm} / \mathrm{m} \text { ) }\end{array}$ & $\begin{array}{c}\text { Total WCT } \\
\geq 75 \mathrm{~mm}\end{array}$ \\
\hline \multicolumn{10}{|c|}{ Lower Akokala Creek } \\
\hline 1 & 1100 & 93 & 6.53 & 1.32 & 1.32 & 1.25 & SS/SG & 0.02 & 2 \\
\hline 2 & 1094 & 60 & 6.59 & 0.51 & 0.76 & 1.00 & SS/SG & 0.00 & 0 \\
\hline 3 & 1102 & 61 & 6.41 & 0.51 & 1.53 & 1.50 & $\mathrm{LG} / \mathrm{CB}$ & 0.02 & 1 \\
\hline 5 & 1134 & 55 & 5.81 & 0.94 & 0.94 & 1.00 & $\mathrm{LG} / \mathrm{CB}$ & 0.05 & 3 \\
\hline 6 & 1173 & 58 & 6.78 & 0.76 & 0.25 & 1.00 & $\mathrm{LG} / \mathrm{CB}$ & 0.05 & 3 \\
\hline 7 & 1184 & 56 & 9.76 & 0.37 & 2.75 & 3.75 & $\mathrm{CB} / \mathrm{LG}$ & 0.18 & 10 \\
\hline 8 & 1214 & 57 & 8.35 & 1.05 & 2.52 & 1.50 & $\mathrm{CB} / \mathrm{LG}$ & 0.18 & 10 \\
\hline 9 & 1239 & 53 & 6.93 & 0.54 & 1.91 & 3.00 & $\mathrm{LG} / \mathrm{CB}$ & 0.26 & 14 \\
\hline 12 & 1357 & 50 & 6.90 & 1.74 & 0.87 & 4.25 & $\mathrm{CB} / \mathrm{BO}$ & 0.36 & 18 \\
\hline 13 & 1404 & 60 & 5.69 & 1.46 & 14.06 & 2.25 & $\mathrm{LG} / \mathrm{CB}$ & 0.17 & 10 \\
\hline 14 & 1435 & 72 & 7.98 & 0.52 & 3.31 & 3.50 & $\mathrm{SG} / \mathrm{LG}$ & 0.08 & 6 \\
\hline 15 & 1460 & 64 & 7.50 & 0.83 & 0.83 & 1.75 & $\mathrm{SG} / \mathrm{LG}$ & 0.00 & 0 \\
\hline \multicolumn{10}{|c|}{ Parke Creek } \\
\hline 16 & 1303 & 51 & 4.39 & 1.79 & 6.25 & 7.50 & $\mathrm{CB} / \mathrm{LG}$ & 0.37 & 19 \\
\hline 17 & 1332 & 50 & 4.11 & 1.95 & 5.35 & 2.00 & SG/SS & 0.08 & 4 \\
\hline 18 & 1344 & 51 & 2.53 & 3.10 & 11.63 & 1.00 & SG/SS & 0.05 & 3 \\
\hline 19 & 1361 & 56 & 3.12 & 2.86 & 17.17 & 5.00 & $\mathrm{SG} / \mathrm{LG}$ & 0.00 & 0 \\
\hline 20 & 1251 & 68 & 4.80 & 0.92 & 2.76 & 2.50 & $\mathrm{CB} / \mathrm{LG}$ & 0.12 & 3 \\
\hline
\end{tabular}

$\mathrm{km}$ intervals along the longitudinal profile of each stream section during the low flow period of August-September 2009 (Fig. 1). Reach lengths ranged from $50 \mathrm{~m}$ to $150 \mathrm{~m}$ to include a minimum of two pools (e.g., deep, low- velocity habitat units that spanned at least half the channel width), and each reach chosen was bounded by a pool at the downstream limit and a natural habitat break (riffle, substrate, or large woody debris aggregate) at the upper limit.

We used a single electrofishing pass without block nets in each sample reach to estimate the minimum abundance of cutthroat trout (>75 mm total length; TL) age-1 and older. Fish less than $75 \mathrm{~mm}$ in TL were considered age- 0 individuals and were not included in abundance and density calculations $[21,26]$. Crews consisted of one person electrofishing and two people netting, sampling the entire available habitat in an upstream direction. Each captured fish was identified to species and their TL was measured (to the nearest $\mathrm{mm}$ ). A fin clip was collected from each fish, preserved in $95 \%$ ethanol, and analyzed at the Conservation Genetics Laboratory at Montana State University, Bozeman, to assess genetic struc- ture (below). Only five juvenile ( $<400 \mathrm{~mm}$ ) bull trout were captured throughout the Akokala Creek watershed in 2009. Therefore, subsequent analyses are restricted to westslope cutthroat trout.

The electrofishing catch of cutthroat trout $(\geq 75 \mathrm{~mm})$ per linear meter of stream (fish captured $/ \mathrm{m}$ ) was used to derive an average catch/m of stream sampled of the larger stream sections Table 2. For comparative purposes, we converted the linear catch of fish to a surface area density (fish captured $/ \mathrm{m}^{2}$ ). The associated habitat area was estimated by multiplying the stream length by the mean wetted width. We then multiplied our estimated minimum density of westslope cutthroat trout by the wetted surface area of the stream to estimate a minimum total abundance for each study section Table 2.

Habitat characteristics were estimated in each sample reach: channel gradient $(\%)$, stream width $(\mathrm{m})$, elevation $(\mathrm{m})$, pool density (pools $/ 100 \mathrm{~m}^{2}$ ), large woody debris (LWD) density $\left(\mathrm{LWD} / 100 \mathrm{~m}^{2}\right)$, and dominant and subdominant substrate types (Table 1). Channel gradient was measured with a hand- 
handheld clinometer, looking upstream and downstream and averaged for each site. Stream width was the average of at least five wetted stream width measurements taken every 10 $\mathrm{m}$ with a tape measure. Elevation was determined using ArcGIS 9.3 (ESRI, Redlands, CA). Pools were enumerated and pool density was calculated (pools $/ 100 \mathrm{~m}^{2}$ ). Large woody debris pieces $(\geq 10 \mathrm{~cm}$ in diameter and $\geq 3 \mathrm{~m}$ in length) within the wetted width were counted and LWD density was calculated (LWD/100m $\mathrm{m}^{2}$ ). Dominant and subdominant substrates were visually estimated in a representative riffle using a modified Wentworth scale (sand and silt, $0.2 \mathrm{~cm}$ ), small gravel $(0.2-0.6 \mathrm{~cm})$, large gravel $(0.6-7.5 \mathrm{~cm})$, cobble $(7.5-$ $30.0 \mathrm{~cm})$, boulders $(>30 \mathrm{~cm})$ and bedrock. Two HOBO U22 temp pro v2 thermographs that recorded hourly water temperatures were deployed in two locations in Akokala Creek during August 2009.

Crews walked the entire extent of available habitat in each stream section to identify potential natural barriers to fish movement and identify suitable locations for artificial barrier placement. Surveyors proceeded upstream, measuring habitat features, such as steep gradients $(>10 \%)$, vertical drops, incised reaches, LWD jams, and notable features were geo-referenced with a GPS unit.

\section{Genetic Structure of Westslope Cutthroat Trout}

We used genetic variation at microsatellite loci to describe the genetic structure of cutthroat in the Akokala watershed. To do this, we genotyped sampled individuals at sixteen microsatellite loci (OclMSU14, OclMSU17, OclMSU16, OclMSU15, OclMSU20, OclMSU21, OclMSU22, OclMSU25, OclMSU23, OclMSU24, OclMSU18, OclMSU19, OclMSU37, OclMSU36, OclMSU34, OclMSU35) specifically developed for describing population structure in westslope cutthroat trout [37]. Testing genotype frequencies at these loci for agreement with Hardy-Weinberg proportions was difficult because of small sample sizes at many of the sampling locations and the possibility there may be genetic differences between sampling locations. Therefore, we conducted Hardy-Weinberg tests on the largest sample: Akokala Lake $(N=25$ individuals). To do this, we used the randomization test of Guo and Thomson [38] as implemented by GENEPOP [39].

The distribution of genetic diversity within sampling sites was quantified by calculating expected heterozygosity averaged across loci. Genetic differences between sampling sites were summarized in several ways. First, we used $\theta$, Weir and Cockerham's [40] version of $F_{S T}$ to quantify genetic differences between each pair of sampling sites. This measure of genetic differentiation ranges from 0 to 1 , with 0 indicating that genetic samples have the same alleles at the same frequencies and 1 indicating that samples are fixed for alternative alleles (i.e., maximally differentiated). We estimated a global $\theta$ for the entire watershed and a matrix of $\theta$ for each pair of populations. We used bootstrapping across loci with 10,000 bootstrapped samples to construct $95 \%$ confidence intervals for estimates of $\theta$. Patterns of genetic differences between populations were further summarized by using the matrix of pairwise $\theta$ to construct a neighbor-joining dendrogram [41]. The topology and branch lengths of the dendrogram were calculated with the computer program TreeFit [42] and a graphical representation of the tree was con- structed with the computer program TreeView [43]. The degree to which the dendrogram fit the data was measured using $R^{2}$ [44]. In addition to these $F_{S T}$ based methods for describing genetic differences between a priori defined sampling locations, the computer program STRUCTURE was used to independently estimate how many genetically distinct populations of cutthroat inhabit the Akokala watershed [45] and to sort individual fish into genetically distinct populations. The specific parameters used to run STRUCTURE were: 20,000 iterations in the "burn in" for the Markov chain, 80,000 iterations of analysis, an admixture model of ancestry for each fish, and one to four possible populations. Default values were used for all other parameters. The analysis was repeated four times to check for convergence.

\section{Criteria for Long-Term Persistence}

We developed four a-priori criteria to evaluate each barrier placement scenario. A barrier placement scenario was either accepted if it met all four criteria or rejected if one of the criteria was not met.

Criterion 1: Maintain suitable stream habitats for salmonid populations

We assessed stream habitat features that are likely necessary to support salmonid populations. Based on the fish population and habitat survey results (described above), we defined suitable habitat as meeting all of the following habitat requirements: (1) cutthroat trout were evenly distributed throughout each section; (2) channel gradients were less than $10 \%$; (3) mean summer water temperatures were less than $15^{\circ} \mathrm{C}$; and (4) pool densities were greater than 0.5 pools $/ 100 \mathrm{~m}^{2}$.

Criterion 2: Maintain an effective population size $(\mathrm{Ne})$ of 500 for long-term persistence.

We estimated the genetic effective population size $\left(N_{e}\right)$ of different sections of the Akokala watershed by estimating the number of adult fish in a section of the watershed, and converting that number to $N_{e}$ by multiplying the number of adults by 0.2 [8] for three barrier placement alternatives. Using a similar approach, we combined the amount of available stream habitat with our minimum estimate of total cutthroat trout abundance in each section to provide an assessment of whether stream populations met the target of 2,500 individuals $(\geq 75 \mathrm{~mm})$, which has been recommended to maintain an effective population size of 500 for long-term population persistence [9]. Because our fish abundance "estimates" are derived from one-pass electrofishing in open reaches of stream, they are extremely conservative and represent minimum counts. Therefore, we estimated $N_{e}$ in each stream section three ways, producing a range of potential abundances and estimates of $N_{e}$. First, the mean catch of cutthroat trout in each stream section was simply multiplied by the stream section length to estimate the abundance of cutthroat trout in each stream section (conservative estimate). Second, we used the mean catch estimate plus one standard deviation of the mean (less conservative), resulting in about a two-fold increase (mean $=1.8$ ) of the mean single-pass catch, which is generally the proportion of westlope cutthroat trout captured on the first pass using multiple depletion population techniques in the Flathead system [34]. Lastly, we used the high cutthroat trout abundance estimate 
Table 2. Mean (Standard Deviation) Observed Abundance Per Linear Meter of Stream and Associated Mean (Standard Deviation) Observed Density of Westslope Cutthroat Trout (WCT) $\geq 75 \mathrm{~mm}$ for the Four Sections of the Akokala Creek Watershed

\begin{tabular}{|c|c|c|c|}
\hline Stream Section & Available Habitat $(\mathbf{k m})$ & Mean Observed WCT Abundance (Fish/m) & Mean Observed WCT Density $\left(\right.$ Fish/ $\left.{ }^{2}\right)$ \\
\hline \hline lower Akokala Creek & 15.8 & $0.09(0.09)$ & $0.01(0.01)$ \\
\hline upper Akokala Creek & 8.6 & $0.17(0.14)$ & $0.02(0.02)$ \\
\hline Parke Creek & 6.6 & $0.13(0.15)$ & $0.03(0.03)$ \\
\hline Long Bow Creek & 5.3 & $0.26(0.10)$ & $0.08(0.04)$ \\
\hline
\end{tabular}

of $0.3 \mathrm{fish} / \mathrm{m}$ as reported by Hilderbrand and Kershner (2000), which equals or exceeds most interior cutthroat trout abundances [7, 8], representing an optimistic scenario for estimating $N_{e}$. We assumed that there were no population losses (i.e., mortality or dispersal) in each of these approaches.

Criterion 3: Maintain distinct genetic groups: barrier does not divide genetically homogeneous populations.

We assessed patterns of genetic structure within the Akokala Creek watershed. Based on these results (described above), we evaluated whether the placement of each barrier scenario would divide a genetically distinct group.

Criterion 4: Maintain long-term genetic diversity.

We used a spatially-explicit, individual-based, riverscape genetics program for aquatic species (CDFISH v0.52) [46] to simulate individual genetic exchange and loss of heterozygostiy as functions of individual-based movement through mating, dispersal, and vital dynamics for the each riverscape barrier scenario. The program provides a framework for simulating population dynamics and the emergence of spatial genetic structure in individuals resulting from specified riverscape processes that govern aquatic species movement behavior.

Our goal was to assess the sensitivity of various barrier scenarios (defined above) on the genetics and demographics of the westslope cutthroat trout population in the Akokala Creek watershed. Therefore, we used the same parameters for all simulations, while changing the riverscape-barrier model. For each barrier scenario, we assumed a complete barrier separating the individuals above and below barrier placements (i.e., no migration allowed across the barrier). Thus, all individuals that were initialized above barrier placements were assumed to be resident to that stream segment and all individuals that were placed below a barrier were allowed to have a migratory life history. A total carrying capacity of 2,334 was used for initialization of individuals following the mean observed abundance in Table 2. For the lower simulations, 2,334 individuals were initialized randomly in a spatial location along the river network and above the barrier placement. In the upper barrier scenario, 670 individuals were initialized randomly above the barrier placement and 1,664 individuals initialized below the barrier placement in the Akokala Creek network. For the Long Bow Creek simulations, 492 individuals were initialized randomly in the Long Bow Creek network above the barrier placement and 1,842 placed below the barrier in the Akokala stream network. The genotypes for each individual were initiated by randomly assigning allelic states across the initial populations following the sampled allele frequency distribution for each of the 16 loci and maximal alleles possible per locus with the $\mathrm{k}$-allele mutation rate set to 0.0005 . The initial sexratio for the entire population was 1.3 males per female [47]. Reproduction was set as heterosexual with a random mating structure within the populations that were separated by a barrier and mate selection chosen based on a male with replacement and a female with replacement. Each mated pair had a constant number of eggs of 287 and the sex assignment included a $43 \%$ change of being a female egg [47]. We did not allow for fluctuating population sizes and, therefore, every generation retained a constant number of individuals (i.e., lambda $=1$ leading to an egg mortality of $99.2 \%$ with the remaining surviving eggs assumed to reach a reproducing adult age). All simulations were run for 50 generations with 10 Monte Carlo replicates to quantify the variability in the spatial genetic structure. For every generation we recorded the genotypes of all individuals, while keeping track of population metrics (i.e., $\mathrm{He}$ ).

\section{RESULTS}

\section{Fish Population and Habitat Surveys}

There was broad overlap in fish population and habitat characteristics among stream sections, suggesting that the majority of habitat in the Akokala Creek watershed, with the exception of high gradient $(>10 \%)$ reaches, is of sufficient quality to support native salmonids (Table 1). Stream temperatures during summer 2009 (July 15-September 15) averaged $13.6^{\circ} \mathrm{C}$ in lower Akokala Creek and $11.7^{\circ} \mathrm{C}$ in upper Akokala Creek, indicating that thermal stressors are likely minimal for native westslope cutthroat trout and bull trout throughout the Akokala Creek watershed [48, 49]. Surveyors did not observe any permanent fish passage barriers, so it is likely that the entire Akokala Creek watershed, including Akokala Lake, is open to invasion by nonnative species.

Mean section elevation generally increased with linear stream distance from the mouth of Akokala Creek, ranging from 1,163 $\mathrm{m}$ in lower Akokala Creek to 1,457 $\mathrm{m}$ in Long Bow Creek. Gradient increased with elevation, with mean average gradient ranging from $1.90 \%$ in lower Akokala Creek to $4.19 \%$ in Long Bow Creek. Mean LWD densities in the headwater sections of the watershed (upper Akokala, Parke and Long Bow creeks) were consistently high, ranging from $4.47 / 100 \mathrm{~m}^{2}$ in upper Akokala Creek to $8.63 / 100 \mathrm{~m}^{2}$ in Parke Creek, with substantially lower LWD density in lower Akokala Creek (mean, 1.33/100m ${ }^{2}$ ). Mean pool density exhibited a similar trend, ranging from $1.06 / 100 \mathrm{~m}^{2}$ in upper Akokala Creek to $2.74 / 100 \mathrm{~m}^{2}$ in Long Bow Creek, with considerably lower pool density in lower Akokala Creek (mean, $0.68 / 100 \mathrm{~m}^{2}$ ), suggesting an increase in habitat complexity with elevation. Cobble $(7.5-30 \mathrm{~cm})$ or large gravel (0.6- 
Table 3. Pairwise Values of $\theta$ Between Sampling Sites. $\theta$ Ranges from 0 (No Genetic Differentiation) to 1.0 (Complete Differentiation). Numbers Correspond to Sampling Location in Fig. (1)

\begin{tabular}{|c|c|c|c|c|c|c|c|c|c|c|c|c|c|c|c|c|c|c|c|}
\hline & 4 & 5 & 6 & 7 & 8 & 9 & 10 & 11 & 12 & 13 & 14 & 15 & 17 & 18 & 20 & 21 & 22 & 23 & 24 \\
\hline 4 & - & 0.000 & 0.000 & 0.000 & 0.000 & 0.000 & 0.011 & 0.000 & 0.024 & 0.000 & 0.005 & 0.001 & 0.023 & 0.000 & 0.009 & 0.027 & 0.048 & 0.043 & 0.051 \\
\hline 5 & 0.000 & - & 0.000 & 0.000 & 0.007 & 0.000 & 0.000 & 0.000 & 0.016 & 0.000 & 0.000 & 0.008 & 0.000 & 0.000 & 0.000 & 0.049 & 0.059 & 0.015 & 0.081 \\
\hline 6 & 0.000 & 0.000 & - & 0.000 & 0.000 & 0.000 & 0.000 & 0.010 & 0.049 & 0.037 & 0.025 & 0.011 & 0.022 & 0.010 & 0.038 & 0.038 & 0.046 & 0.074 & 0.086 \\
\hline 7 & 0.000 & 0.000 & 0.000 & - & 0.000 & 0.000 & 0.025 & 0.003 & 0.031 & 0.012 & 0.010 & 0.003 & 0.006 & 0.000 & 0.021 & 0.025 & 0.008 & 0.050 & 0.068 \\
\hline 8 & 0.000 & 0.007 & 0.000 & 0.000 & - & 0.000 & 0.037 & 0.008 & 0.030 & 0.028 & 0.014 & 0.018 & 0.021 & 0.000 & 0.037 & 0.054 & 0.055 & 0.061 & 0.098 \\
\hline 9 & 0.000 & 0.000 & 0.000 & 0.000 & 0.000 & - & 0.000 & 0.000 & 0.015 & 0.010 & 0.000 & 0.011 & 0.016 & 0.000 & 0.015 & 0.024 & 0.027 & 0.039 & 0.061 \\
\hline 10 & 0.011 & 0.000 & 0.000 & 0.025 & 0.037 & 0.000 & - & 0.000 & 0.014 & 0.003 & 0.000 & 0.035 & 0.008 & 0.007 & 0.000 & 0.016 & 0.069 & 0.033 & 0.071 \\
\hline 11 & 0.000 & 0.000 & 0.010 & 0.003 & 0.008 & 0.000 & 0.000 & - & 0.022 & 0.000 & 0.000 & 0.006 & 0.020 & 0.010 & 0.000 & 0.025 & 0.042 & 0.038 & 0.066 \\
\hline 12 & 0.024 & 0.016 & 0.049 & 0.031 & 0.030 & 0.015 & 0.014 & 0.022 & - & 0.006 & 0.014 & 0.021 & 0.019 & 0.002 & 0.007 & 0.009 & 0.051 & 0.088 & 0.135 \\
\hline 13 & 0.000 & 0.000 & 0.037 & 0.012 & 0.028 & 0.010 & 0.003 & 0.000 & 0.006 & - & 0.000 & 0.000 & 0.000 & 0.004 & 0.000 & 0.000 & 0.054 & 0.036 & 0.098 \\
\hline 14 & 0.005 & 0.000 & 0.025 & 0.010 & 0.014 & 0.000 & 0.000 & 0.000 & 0.014 & 0.000 & - & 0.000 & 0.005 & 0.000 & 0.016 & 0.038 & 0.069 & 0.054 & 0.118 \\
\hline 15 & 0.001 & 0.008 & 0.011 & 0.003 & 0.018 & 0.011 & 0.035 & 0.006 & 0.021 & 0.000 & 0.000 & - & 0.014 & 0.008 & 0.014 & 0.008 & 0.034 & 0.060 & 0.089 \\
\hline 17 & 0.023 & 0.000 & 0.022 & 0.006 & 0.021 & 0.016 & 0.008 & 0.020 & 0.019 & 0.000 & 0.005 & 0.014 & - & 0.010 & 0.006 & 0.010 & 0.041 & 0.030 & 0.085 \\
\hline 18 & 0.000 & 0.000 & 0.010 & 0.000 & 0.000 & 0.000 & 0.007 & 0.010 & 0.002 & 0.004 & 0.000 & 0.008 & 0.010 & - & 0.004 & 0.037 & 0.049 & 0.021 & 0.085 \\
\hline 20 & 0.009 & 0.000 & 0.038 & 0.021 & 0.037 & 0.015 & 0.000 & 0.000 & 0.007 & 0.000 & 0.016 & 0.014 & 0.006 & 0.004 & - & 0.027 & 0.018 & 0.060 & 0.079 \\
\hline 21 & 0.027 & 0.049 & 0.038 & 0.025 & 0.054 & 0.024 & 0.016 & 0.025 & 0.009 & 0.000 & 0.038 & 0.008 & 0.010 & 0.037 & 0.027 & - & 0.050 & 0.063 & 0.104 \\
\hline 22 & 0.048 & 0.059 & 0.046 & 0.008 & 0.055 & 0.027 & 0.069 & 0.042 & 0.051 & 0.054 & 0.069 & 0.034 & 0.041 & 0.049 & 0.018 & 0.050 & - & 0.094 & 0.096 \\
\hline 23 & 0.043 & 0.015 & 0.074 & 0.050 & 0.061 & 0.039 & 0.033 & 0.038 & 0.088 & 0.036 & 0.054 & 0.060 & 0.030 & 0.021 & 0.060 & 0.063 & 0.094 & - & 0.047 \\
\hline 24 & 0.051 & 0.081 & 0.086 & 0.068 & 0.098 & 0.061 & 0.071 & 0.066 & 0.135 & 0.098 & 0.118 & 0.089 & 0.085 & 0.085 & 0.079 & 0.104 & 0.096 & 0.047 & - \\
\hline
\end{tabular}

$7.5 \mathrm{~cm})$ substrates were most commonly encountered in all stream sections (Table 1).

Westslope cutthroat trout $(N=272$, length range 35$335 \mathrm{~mm}$ ) were widely distributed in the Akokala Creek watershed; they were detected in nine of ten sites in lower Akokala Creek, four of five sites in Parke Creek, all four sites in Long Bow Creek and four of five sites in upper Akokala Creek, in addition to Akokala Lake. The highest catch of westslope cutthroat trout was observed in Long Bow Creek (Table 1). Mean estimated densities (fish $\geq 75 \mathrm{~mm} / \mathrm{m}^{2}$ ) were very similar in lower Akokala Creek, upper Akokala Creek and Parke Creek, but were substantially higher in Long Bow Creek (Table 1). Bull trout $(N=5$, length range, $85-448 \mathrm{~mm}$ ) were rarely observed; they were detected only in sites 12, 14 and 15 in upper Akokala Creek.

\section{Genetic Structure of Westslope Cutthroat Trout}

There were no noteworthy departures from HardyWeinberg expectations in the genotypes from Akokala Lake. Out of the 16 loci genotyped, only one showed a $P$-value less than 0.05 , and this was not statistically significant at the 0.05 level when a bonferronni adjustment was made for multiple comparisons.

The sampling sites in the Akokala watershed contained typical amounts of genetic diversity for cutthroat trout popu- lation throughout their current range [50]. The number of alleles per locus ranged from seven to 24 with a mean of 13.3. The expected heterozygosity within populations ranged from 0.64 to 0.80 with an average across all locations and loci of 0.74 . The population with the lowest heterozygosity was from the headwaters of Long Bow Creek, and the four samples from Long Bow Creek had some of the lowest levels of heterozygosity in the Akokala watershed. In fact, the four locations sampled in Long Bow Creek were four of the least variable populations sampled. There appears to be a trend in the watershed for less genetic diversity in headwater populations (Spearman rank test, $P=0.06$ ).

Analysis of population structure showed generally modest amounts of genetic differentiation between locations sampled in the watershed (Table 3 ). The global value of $\theta$ for the 19 locations for which genetic samples were available was 0.021 with a $95 \%$ confidence interval of $(0.012,0.030)$. The $R^{2}$ value for the dendrogram was 0.86 , which seems fairly high considering the small sample size in many of the locations. The only notable genetic structure present in the dendrogram is that fish from Long Bow Creek were genetically distinct from the other sampling sites (Fig. 2). Aside from this genetic division, fish from the rest of the sampling locations were genetically very similar to each other. This was especially true for fish in the lower mainstem Akokala (i.e., below the confluence with Parke Creek). Results from 
Table 4. Projected Population Size $(N)$ of Westslope Cutthroat Trout $(W C T)$ in the Four Sections of the Akokala Creek Watershed Using the Following Estimation Techniques: Mean Westslope Cutthroat Trout Site Abundance (Fish/m, see Table 2), + 1 Standard Deviation (SD) Mean Site Abundance (See Table 1) and a Standard "High" Abundance of 0.3 Fish/m, as Established by Hilderband and Kershner (2000)

\begin{tabular}{|c|c|c|c|}
\hline & \multicolumn{3}{|c|}{ Projected Number of WCT } \\
\hline Stream Section & Mean Observed WCT Abundance & + 1 SD of Mean Observed WCT Abundance & 0.3 fish/m \\
\hline \hline lower Akokala Creek & 1478 & 2838 & 4730 \\
\hline upper Akokala Creek & 1454 & 2680 & 2594 \\
\hline Parke Creek & 883 & 1851 & 1983 \\
\hline Long Bow Creek & 1363 & 1967 & 1595 \\
\hline
\end{tabular}

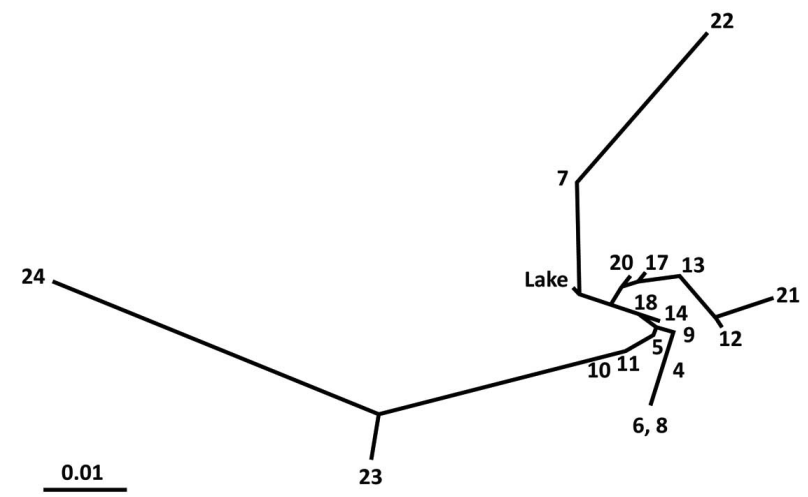

Fig. (2). Population genetic structure denogram for westslope cutthroat trout in the Akokala Creek watershed. Site numbers are identified in Table 1.

the computer program STRUCTURE were consistent with low levels of genetic differentiation in the watershed. The model of population structure with the highest likelihood was a single randomly mating population.

\section{Long-Term Genetic Diversity}

We used CDFISH to examine the potential impacts of isolation on long-term genetic diversity $\left(H_{e}\right)$ for each barrier scenario (Fig. 3). Simulation results suggest that placing the barrier near the mouth of Akokala Creek would maintain a relatively constant $H_{e}$, with an estimated loss of only $0.4 \%$ (0.752 to 0.749$)$ over 50 generations (Fig. 3). In contrast, placing the barrier in the headwater areas would likely cause a more substantial loss of $H_{e}$ over 50 generations as compared to the barrier near the mouth scenario; $H_{e}$ declines approximately $6 \%(0.752$ to 0.710$)$ for the isolated population in Long Bow Creek, about 4\% (0.752 to 0.722) for the population isolated in upper Akokala Creek, and less than 1\% for downstream populations for each of these scenarios.

\section{Isolation Management Scenarios}

We used the combined fish habitat, population and genetics results to determine whether each barrier placement scenario met each of the four persistence criteria, (suitable habitat availability, $N_{e}=500$, no additional genetic subdivision, and maintenance of long-term genetic diversity); all scenarios met the criteria for suitable stream habitat.

Scenario 1 will isolate the entire Akokala Creek watershed by placing a barrier near the confluence of Akokala Creek and the North Fork of the Flathead River (Fig. 1)

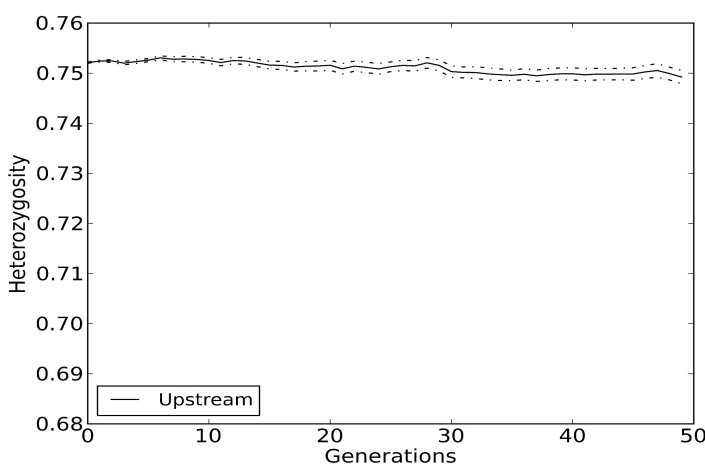

(a)

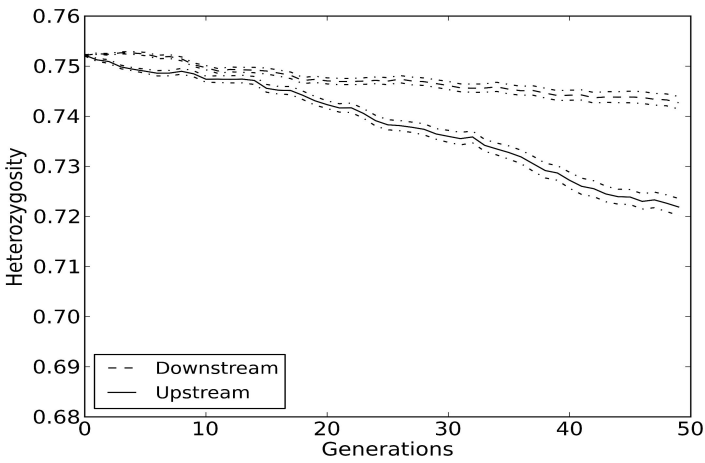

(b)

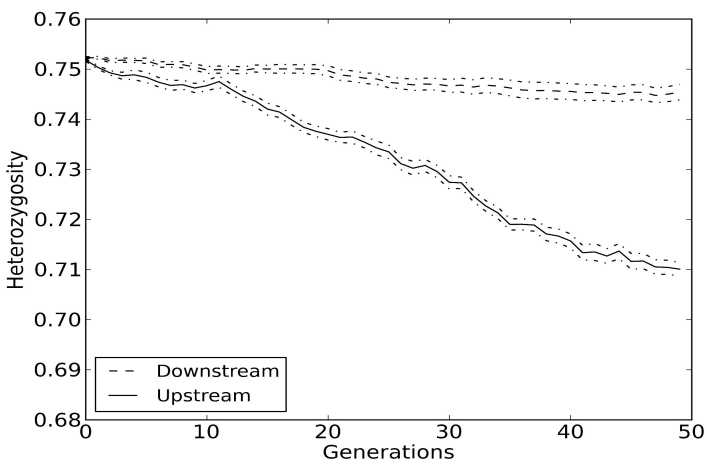

(c)

Fig. (3). Results of a spatially-explicit, individual-based, riverscape genetics program (CDFISH v0.52) to examine the potential impacts of isolation on long-term genetic diversity (heterozygosity, $H_{e}$ ) for populations upstream and downstream for each barrier scenario. Barrier placement scenarios (see Methods) are: (a) near the mouth of Akokala Creek; (b) upper Akokala Creek; and (c) the mouth of Long Bow Creek (Fig. 1). 
Table 5. Projected Population Size $(N)$ of Isolated Westslope Cutthroat Trout $(W C T) \geq 75$ mm Under Each Barrier Placement Scenario as Estimated by Mean Westslope Cutthroat Trout Site Abundance (Fish/m), Mean Site Abundance +1 Standard Deviation (SD), and a Standard "High" Abundance of $0.3 \mathrm{Fish} / \mathrm{m}$, as Established by Hilderbrand and Kershner (2000)

\begin{tabular}{|c|c|c|c|c|}
\hline \multirow{2}{*}{ Scenario } & \multicolumn{3}{|c|}{ Projected $N$ Isolated WCT } \\
\hline Isolated Habitat $(\mathbf{k m})$ & $\begin{array}{c}\text { Mean Observed WCT } \\
\text { Abundance }\end{array}$ & $\begin{array}{c}\text { + 1 SD of Mean Observed WCT } \\
\text { Abundance }\end{array}$ & \multicolumn{1}{|c|}{ 0.3 fish/m } \\
\hline \hline 1) Barrier at mouth of Akokala Creek & 36.6 & 5178 & 9336 & 10902 \\
\hline 2) Barrier on upper Akokala Creek & 8.6 & 1454 & 2680 & 2594 \\
\hline 3) Barrier on Long Bow Creek & 5.3 & 1363 & 1967 & 1595 \\
\hline
\end{tabular}

potentially at the North Fork Road bridge crossing. This option will provide $36.6 \mathrm{~km}$ of isolated stream habitat but will eliminate access by migratory fish from the wider Flathead watershed. Estimates of isolated westslope cutthroat trout population size ranged from 5,178 fish $\geq 75 \mathrm{~mm}$, using mean observed abundance (fish/m) for each isolated stream section, to 10,902 fish $\geq 75 \mathrm{~mm}$, assuming the high abundance of $0.30 \mathrm{fish} / \mathrm{m}$ throughout each stream section Tables 4 and 5. Although these estimates did not include fish from Akokala Lake, even our most conservative approach suggests that a minimum $N_{e}=500$ westslope cutthroat trout would be maintained under this scenario. Additionally, this scenario would result in the least amount of genetic diversity lost over 50 generations $(0.4 \%)$ as compared to the other two alternatives (Fig. 3).

Scenario 2, placing a barrier on upper Akokala Creek above the confluence with Long Bow Creek (Fig. 1), would isolate $8.6 \mathrm{~km}$ of stream habitat, in addition to Akokala Lake, while leaving $28 \mathrm{~km}$ accessible to migratory westslope cutthroat trout from the wider Flathead River drainage. Our conservative abundance estimate $(1,454$ fish $\geq 75 \mathrm{~mm})$ suggests that isolation of upper Akokala Creek may not maintain a population of 2,500 individuals, or an $N_{\mathrm{e}}=500$ Tables 4 and 5. Less conservative abundance estimates barely met the target population size; assuming an abundance of 0.30 fish/m projected 2,594 fish $\geq 75 \mathrm{~mm}$, and using an intermediate estimate using an assumed sampling efficiency of $\sim 50 \%$ (i.e., + 1 standard deviation of the mean; $0.41 \mathrm{fish} / \mathrm{m}$ ) projected 2,680 fish $\geq 75 \mathrm{~mm}$ Tables 4 and $\mathbf{5}$. We did not estimate the number of fish occupying Akokala Lake, so these estimates are likely an underestimate of the total population size inhabiting upper Akokala Creek. However, fragmenting upper Akokala Creek appears to pose greater longterm demographic risk and will not meet the additional persistence criteria of no population subdivision and loss of genetic diversity (estimated $4 \%$ loss over 50 generations), as compared to the scenario of installing a barrier near the mouth of Akokala Creek.

Placing a barrier on Long Bow Creek near its confluence with Akokala Creek under Scenario 3 (Fig. 1) would provide the least amount of isolated habitat $(5.3 \mathrm{~km})$, but leave the largest portion of the watershed open to migratory fish $(31.3 \mathrm{~km})$. This barrier option is logistically the most difficult of the three due to the remoteness of the site and the relatively unconfined channel type near the confluence of Long Bow and Akokala creeks. Moreover, this barrier location would not secure the bull trout population in Akokala Lake from lake trout invasion from nearby sources. How- ever, this alternative would meet the criteria of no population subdivision because it would isolate a genetically distinct population of cutthroat trout in the creek. Despite genetic results suggesting that some reproductive isolation is present in Long Bow Creek, none of our population scenarios met the guideline size of 2,500 individuals and the likelihood of this small creek supporting an $N_{\mathrm{e}}$ of 500 over the long-term appears low Tables $\mathbf{4}$ and $\mathbf{5}$.

\section{DISCUSSION}

Increasingly, isolation management is being used to protect headwater populations of cutthroat trout in western North America [8, 10, 11]. The westslope cutthroat trout is native to the upper Columbia, upper Missouri, and South Saskatchewan River drainages in western North America and has the largest range of the 12 extant subspecies of cutthroat trout in North America [5]. However, non-hybridized populations persist in less than $10 \%$ of their historic range, with many restricted to small, fragmented headwater habitats, where their long-term sustainability is uncertain [51]. In this case study, the probability of hybridization spreading upstream into Akokala Creek from downstream nearby hybrid and rainbow trout source populations is very likely [27, 28, $32,34]$. In fact, this may already be occurring as one hybridized radio-tagged fish (with low levels of admixture) recently spawned in the lower portion of Akokala Creek [32]. Our data suggest that placing a barrier near the mouth at the North Fork Flathead River would provide the largest habitat patch size with the largest population size possible within the system. However, isolation of the entire watershed would disrupt or could eliminate the migratory component of the westslope cutthroat trout population in Akokala Creek, thus reducing genetic diversity and adaptive potential of the subspecies and populations in the upper Flathead system.

One option to mitigate these potential effects of isolation is to selectively pass migratory fish upstream of the barrier as they enter Akokala Creek to spawn. Recent advances in development of diagnostic genetic markers for species identification, such as microsatellites and diagnostic single nucleotide polymorphisms (SNPs) for distinguishing westslope cutthroat trout and rainbow trout, provide the statistical power to detect very small amounts of admixture $(<1 \%)$ in individual fish. Therefore, selectively moving nonhybridized individuals, as determined by rapid genetic analyses, could be employed to maintain genetic diversity and a migratory life history component over time until long-term management strategies are implemented to eradicate or reduce nearby nonnative fish sources. Pro-active conservation 
measures, such as removing hybrid adults during spawning and allowing harvest of rainbow trout, are currently being implemented in lower portions of system to slow or stop the spread of hybridization.

The pattern of genetic variation of westslope cutthroat trout revealed by microsatellites indicates some geographic and genetic structuring within in the Akokala Creek watershed. We found a modest level of genetic divergence between samples collected in Long Bow Creek and those collected elsewhere within the watershed, suggesting that there has been limited genetic exchange between fish in Long Bow Creek and the rest of the Akokala Creek watershed. One potential explanation for this is differences in life history. Migratory westslope cutthroat trout from the Flathead River have been documented spawning in the Akokala Creek mainstem downstream of Long Bow Creek [32], so it is likely that the Long Bow Creek population may exhibit a resident life history (i.e., individuals remain in the natal stream their entire lives). Examination of the lengthfrequency distribution of westslope cutthroat trout sampled in Low Bow Creek revealed relatively older (resident) fish as compared with the other sampling locations in the watershed, indicating that a resident component likely exists. With limited gene flow, over time even weak selection differences can result in local adaptations in trout populations.

Although isolation management is being widely used to protect headwater populations of trout, situations involving sympatric native migratory species, such as bull trout, require additional considerations. Our results and previous studies [31] suggest that the Akokala Creek drainage contains a small, disjunct adfluvial bull trout population and represents a situation where constructing a barrier in the lower portion of the watershed would likely benefit both native salmonids. In addition to threats to bull trout posed by lake trout invasion, the Akokala watershed and other nearby aquatic systems may be at risk for future invasion by nonnative brook trout (S. fontinalis) [23], which can hybridize with bull trout [52] and can outcompete cutthroat trout at young ages [53].

Basin-wide stream habitat and fish abundance surveys and corresponding genetic analyses and simulations provided complementary information to identify potential locations for barrier placement and to understand the potential longterm impacts of isolation on population viability within a water-shed chosen for barrier placement. Our study highlights the importance of sampling design in studies of salmonids and other freshwater organisms that exhibit finescale genetic structure and complex life histories and native species assemblages. Designing studies in a hierarchical manner so that multiple samples within streams and across drainages are taken is essential when advising isolation management options within complex stream networks. Recent and ongoing advancements in molecular markers, provide rapid and high-resolution approaches to understanding contemporary patterns of genetic diversity that were previously unavailable to managers as a tool to assess patterns of genetic diversity across small spatial scales within watersheds. Furthermore, recent developments of spatially-explicit, landscape genetic simulators, such as CDFISH, provide a powerful tool for researchers to test specific hypotheses about the influence of stream features (e.g., barriers) and a wide range of environmental scenarios (e.g., changes in temperature and flow) on gene flow and connectivity in complex riverscapes.

Our estimates of the amount of genetic diversity that will be retained in isolated populations should be interpreted with a healthy dose of caution. The rate at which genetic diversity in populations is lost depends on many factors including: the number of breeding adults in a population, the sex ratio of the population, the variance in reproductive success among individuals, the degree of population fluctuation, the number of times individuals reproduce, and the extent to which individuals in the population mate randomly. Obtaining values for all of these parameters is difficult. The simulations that we performed had reasonable estimates for the number of breeding adults and the sex ratio of the populations, and used a plausible model for non-random mating. We did not have estimates for variance in reproductive success or population size, so we did not include these processes in the simulations. Therefore, our estimates of how much genetic diversity would be maintained under each barrier placement scenario are probably optimistic.

\section{CONCLUSION}

We present an applied case study for assessing the potential impacts of using isolation to conserve native salmonids at risk from nonnative fish invasions in a regional stronghold. Due to the high threat of invasion by nonnative salmonids from nearby sources [23, 27, 28, 32, 34] resource managers are interested in using a barrier to upstream fish movement as a long-term solution to protect existing nonhybridized westslope cutthroat trout and threatened bull trout populations in the Akokala Creek watershed. Our results suggest that there are varying levels of risk for maintaining long-term population viability among the three barrier placement scenarios. We found that isolation of small headwater streams may not provide sufficient stream habitat and individuals necessary to maintain long-term genetic integrity, and that isolation of the entire watershed is likely the best option to minimize genetic and demographic risks associated with small population sizes. We recommend similar fine-scale (stream- and watershed-level), systematic analyses of stream habitat, fish population and genetic structure to assess the pros and cons of barrier placement within streams identified for potential isolation management. This approach may be used by managers to make informed decisions for conservation of remaining native trout populations in GNP and elsewhere.

A primary limitation to the use of broad-scale assessments in evaluating the use of artificial barriers is their coarse spatial resolution and poorly resolved evaluation of demographic and genetic impacts of barrier placement on fish populations within streams. Consequently, most broadscale evaluations within large stream networks are less reliable in determining local spatial- and temporal-scale features that are essential for isolation management assessments for biological communities, especially for species with small distributions and fine-scale genetic and life history structuring. We suggest that high-resolution (stream- and watershedspecific) biological, genetic, and physical habitat assessments, as described herein, are needed in conjunction with 
the broader more general isolation management assessments in heterogenous stream networks [10] to evaluate the pros and cons of isolation strategies. Such an approach allows competing considerations, such as accessibility for construction, to be weighed against biological considerations. Furthermore, because climate change is likely to exacerbate existing problems of habitat degradation and introduced salmonids, understanding the increased risk from climate change is needed to inform isolation management opportunities and may require increased control efforts for invasive nonnative species [7]. We recommend a two-stage approach of broad scale and high resolution assessments that will enable managers to comprehensively understand the complexities of using barriers and reliably evaluate the potential impacts on native salmonid species from local population to metapopulation scales.

\section{ACKNOWLEDGEMENTS}

We thank C. Fredenberg, B. Galloway, and T. Marotz for assistance in the field, J. J. Giersch for developing the study area map, N. Vu for all laboratory genetic analyses, and P. VanEimeren and A. Todd for their review of a previous draft. Funding was provided by Montana Fish, Wildlife \& Parks, Bonneville Power Administration, and the National Science Foundation (DEB 0717456). Any use of trade, product, or firm names is for descriptive purposes only and does not imply endorsement by the U.S. Government. This research was conducted in accordance with the Animal Welfare Act and its subsequent amendments.

\section{CONFLICT OF INTEREST}

None declared.

\section{REFERENCES}

[1] Vitousek PM, Mooney HA, Lubchenco J, Melillo JM. Human domination of earth's ecosystems. Science 1997; 277(5325): 494-9.

[2] Rahel FJ. Homogenization of fish faunas across the United States. Science 2000; 288(5467): 854-6.

[3] Miller RR, Williams JD, Williams JE. Extinction of north american fishes during the past century. Fisheries 1989; 14(6): 22-38.

[4] Allan JD, Flecker AS. Biodiversity conservation in running waters. Bioscience 1993; 43: 32-43.

[5] Behnke RJ. Native trout of western North America. American Fisheries Society, Bethesda, Maryland 1992.

[6] Williams JE, Johnson JE, Hendrickson DA, et al. Fishes of north america endangered, threatened, or of special concern. Fish 1989; 14(6): 2-20.

[7] Williams JE, Haak AL, Neville HM, Colyer WT. Potential consequences of climate change to persistence of cutthroat trout populations. N Am J Fish Manage 2009; 29: 533-48.

[8] Hilderbrand RH, Kershner JL. Conserving inland cutthroat trout in small streams: How much stream is enough? N Am J Fish Manage 2000; 20: 513-20.

[9] Franklin IR. Evolutionary changes in small populations. In: Soule ME, Wilcox BA, editors. Conservation biology: an evolutionaryecological perspective. Sinauer Associates; Sunderland, Massachusetts: 1980.

[10] Fausch KD, Rieman BE, Dunham JB, Young MK, Peterson DP. Invasion versus isoloation: Trade-offs in managing native salmonids with barriers to upstream movement. Conserv Biol 2009; 23(4): 859-70.

[11] Peterson DP, Rieman BE, Dunham JB, Fausch KD, Young MK. Analysis of trade-offs between threats of invasion by nonnative brook trout (Salvelinus fontinalis) and intentional isolation for native westslope cutthroat trout (Oncorhynchus clarkii lewisi). Can J Fish Aquat Sci 2008; 65: 557-73.
[12] Thompson PD, Rahel FJ. Evaluation of artificial barriers in small rocky mountain streams for preventing the upstream movement of brook trout. N Am J Fish Manag 1998; 18: 206-10.

[13] Novinger DC, Rahel FJ. Isolation management with artificial barriers as a conservation strategy for cutthroat trout in small headwater streams. Conserv Biol 2003; 17: 772-81.

[14] Fausch KD, Rieman BE, Young MK, Dunham JB. Strategies for conserving native salmonid populations at risk from nonnative fish invasions: tradoffs in using barriers to upstream movement. USDA Forest service, Rockey Mountain Research Station, RMRS-GTR174, 2006.

[15] Crandall KA, Bininda-Emonds ORP, Mace GM, Wayne RK. Considering evolutionary processes in conservation biology. Tree 2000; 15(7): 290-5.

[16] Spruell P, Rieman BE, Knudsen KL, Utter FM, Allendorf FW. Genetic population structure within streams: microsatellite analysis of bull trout populations. Ecol Freshw Fish 1999; 8(3):114-21.

[17] Leary RF, Allendorf RW, Phelps SR, Knudsen KL. Genetic divergence and identification of seven cutthroat trout subspecies and rainbow trout. Trans Am Fish Soc 1987; 116: 580-7.

[18] Taylor EB, Costello AB. Microsatellite DNA analysis of coastal populations of bull trout (Salvelinus confluentus) in british columbia: zoogeographic implications and its application to recreational fishery management. Can J Fish Aquat Sci 2006; 63(5): 1157-71.

[19] Rieman BE, Dunham JB. Metapopulations and salmonids: a synthesis of life history patterns and empirical observations. Ecol Freshw Fish 2000; 9: 51-64.

[20] Liknes GA, Graham PJ. Westslope cutthroat trout in montana: life history, status, and management. American Fisheries Society Symposium 1988; 4: 53-60.

[21] Fraley JJ, Shepard BB. Life history, ecology and population status of bull trout (Salvelinus confluentus) in the Flathead lake and river system, Montana. Northwest Sci 1989; 63: 133-43.

[22] Drinan DP, Kalinowsk ST, Ninh VV, Shepard BB, Muhlfeld CC, Campbell MR. Genetic variation in westslope cutthroat trout Oncorhynchus clarkii lewisi: implications for conservation. Conserv Genet 2011; 12: 151-23

[23] Fredenberg W. Further evidence that lake trout displace bull trout in mountain lakes. Int J Sci 2002; 8(3):143-52.

[24] Meeuwig MH, Guy CS, Fredenberg WA. Influence of landscape characteristics on fish species richness among lakes of Glacier National Park, Montana. Int J Sci 2008; 14(1-3): 1-16.

[25] Martinez PJ, Bigelow PE, Deleray MA, et al. Western lake trout woes. Fish 2009; 34: 424-42.

[26] Muhlfeld CC, Kalinowshi ST, McMahon TE, et al. Hybridization rapidly reduces reproductive success of a native trout in the wild. Biol Lett 2009; 5: 328-31.

[27] Hitt NP, Frissell CA, Muhlfeld CC, Allendorf FW. Spread of hybridization between native westslope cutthroat trout, Oncorhynchus clarki lesisi, and nonnative rainbow trout, Oncorhynchus mykiss. Can J Fish Aquat Sci 2003; 60(12):1440-51.

[28] Boyer MC, Muhlfeld CC, Allendorf FW. Rainbow trout (Oncorhynchus mykiss) invasion and the spread of hybridization with native westslope cutthroat trout (Oncorhynchus clarkii lewisi). Can J Fish Aquat Sci 2008; 65(4): 658-69.

[29] Meeuwig MH. Ecology of lacustrine-adfluvial bull trout populations in an interconnected system of natural lakes. Bozeman, MT: Montana State University; 2008.

[30] Ellis BK, Stanford JA, Goodman D, et al. Long-term effects of a trophic cascade in a large lake ecosystem. Proc Natl Acad Sci 2011;108:1070-5.

[31] Meeuwig MH, Guy CS, Kalinowshi ST, Fredenberg WA. Landscape influences on genetic differentiation among bull trout populations in a stream-lake network. Mol Ecol 2010; 19: 3620-33.

[32] Muhlfeld CC, McMahon TE, Belcer D. Spatial and temporal spawning dynamics of native westslope cutthroat trout (Oncorhynchus clarkii lewisi), introduced rainbow trout $(O$. mykiss), and their hybrids. Can J Fish Aquat Sci 2009; 66: 1153-68.

[33] Shepard BB, May BE, Urie W, Pratt KL, Graham PJ. Life histories of westslope cutthroat trout and bull trout in the upper Flathead river basin, Montana. Helena, MT: Montana Department of Fish, Wildlife and Parks 1984.

[34] Muhlfeld CC, McMahon TE, Boyer MC, Gresswell RE. Localhabitat, watershed and biotic factors in the spread of hybridization 
between native westslope cutthroat trout and introduced rainbow trout. Trans Am Fish Soc 2009; 138(5): 1036-51.

[35] Hankin DG, Reeves GH. Estimating total fish abundance and total habitat area in small streams based on visual estimation methods. Can J Fish Aquat Sci 1988; 45: 834-44.

[36] Muhlfeld CC, Bennett DH, Marotz B. Summer habitat use by columbia river redband trout in the kootenai river drainage, montana. N Am J Fish Manage 2001; 21(1): 223-35.

[37] Vu NV, Kalinowsk ST. Twelve tetranucleotide microsatellite loci for westslope cutthroat trout Oncorhynchus clarki lewisi (Salmonidae) Conserv Genet Resour 2009; 1: 249-51.

[38] Guo SW, Thompson EA. Performing the exact test of HardyWeinberg proportions for multiple alleles. Biometrics. 1992; 48: $361-72$.

[39] Raymond M, Rousset F. GENEPOP (version 1.2): population genetics software for exact tests and ecumenicism. Heredity 1995; 86: 248-9.

[40] Weir BS, Cockerham CC. Estimating f-statistics for the analysis of population structure. Evolution 1984; 38: 1358-70.

[41] Saitou N, Nei M. The neighbor-joining method: a new method for reconstructing phylogenetic trees. Mol Biol Evol 1987; 4: 406-25.

[42] Kalinowski ST, Meeuwig MH, Narum SR, Taper ML. Stream trees: a statistical method for mapping genetic differences between populations of freshwater organisms to the sections of streams that connect them. Can J Fish Aquat Sci 2008; 65(12): 2752-60.

[43] Page RDM. TREEVIEW: An application to display phylogenetic trees on personal computers. Comput Appl Biosci 1996; 12: 357-8.

[44] Kalinowski ST. How well do evolutionary trees describe genetic relationships between populations?. Heredity 2009; 102: 506-13.

[45] Pritchard JK, Stephens M, Donnelly P. Inference of population structure using multilocus genotype data. Genetics 2000; 155: 94559.
[46] Landguth EL, Muhlfeld CC, Luikart G. CDFISH: an individualbased, spatially explicit, landscape genetics simulator for aquatic species in complex riverscapes. Conserv Genet Resour 2011. DOI: 10.1007/S12686-011-9492-6.

[47] Downs CC, White RG, Shepard BB. Age at sexual maturity, sex ratio, fecundity, and longevity of isolated headwater populations of westslope cutthroat trout. N Am J Fish Manage 1997; 17: 85-92.

[48] Selong JH, McMahon TE, Zale AV, Barrows FT. Effect of temperature on growth and survival of bull trout, with application of an improved method for determining thermal tolerance in fishes. Trans Am Fish Soc 2001; 130(6): 1026-37.

[49] Bear EA, McMahon TE, Zale AV. Comparative thermal requirements of westslope cutthroat trout and rainbow trout: Implications for species interactions and development of thermal protection standards. Trans Am Fish Soc 2007; 136(4): 1113-21.

[50] Drinan DP, Kalinowsk ST, Ninh VV, Shepard BB, Muhlfeld CC Campbell MR. Genetic variation in westslope cutthroat trout Oncorhynchus clarkii lewisi: implications for conservation. Conserv Genetics. 2011; 12: 1513-23

[51] Shepard BB, May BE, Urie W. Status and conservation of westslope cutthroat trout within the western United States. N Am J Fish Manage 2005; 25(4): 1426-40.

[52] Kanda N, Leary RF, Allendorf FW. Evidence of introgressive hybridization between bull trout and brook trout. Trans Am Fish Soc 2002; 131(4): 772-82.

[53] Peterson DP, Fausch KD, Watmough J, Cunjak RA. When eradication is not an option: modeling strategies for electrofishing suppresion of nonnative brook trout to foster persistence of sympatric native cutthroate trout in small streams. N Am J Fish Manage 2008; 28: 1847-67.

(c) Muhlfeld et al.; Licensee Bentham Open.

This is an open access article licensed under the terms of the Creative Commons Attribution Non-Commercial License (http://creativecommons.org/licenses/ by-nc/3.0/) which permits unrestricted, non-commercial use, distribution and reproduction in any medium, provided the work is properly cited. 